Pérez-Salazar, A., Cano, F. H. \& García-Blanco, S. (1978). Cryst. Struct. Commun. 7, 105-109.

Porte, A. L. \& Robertson, J. M. (1959). J. Chem. Soc. pp. 825-829.

SHELDRICK, G. M. (1976). SHELX76. Program for crystal structure determination. Univ. Chemistry Laboratory, Cambridge Univ., England.

Spirlet, M. R., Dupont, L., DideberG, O. \& Kapundu, M. (1980). Acta Cryst. B36, 1593-1598.

Stewart, R. F., Davidson, E. R. \& Simpson, W. T. (1965). J. Chem. Phys, 42, 3175-3187.

Stoeckli-Evans, H. (1979a). Acta Cryst. B35, 231-234.

Stoeckli-Evans, H. (1979b). Acta Cryst. B35, 2798-2800.
Stoeckli-Evans, H. \& Crout, D. H. G. (1976). Helv. Chim. Acta, 59, 2168-2178.

Sussman, J. L. \& WodaK, S. J. (1973). Acta Cryst. B29, 2918-2926.

TAshkhodzhaev, B., Telezhenetskaya, M. V. \& Yunusov, S. Yu. (1979). Khim. Prir. Soedin. No. 3, pp. 363-367.

Tashkhodzhaev, B., Yagudaev, M. R. \& Yunusov, S. Yu. (1979). Khim. Prir. Soedin. No. 3, pp. 368-373.

Warren, F. L. (1966). Fortschr. Chem. Org. Naturst. 24, 329-406.

Wodak, S. J. (1975). Acta Cry'st. B31, 569-573.

Acta Cryst. (1982). B38, 159-162

\title{
The Structure of 6,9-Dichloro-2-methoxyacridine
}

\author{
By Stephen NeIDLE \\ Cancer Research Campaign Biomolecular Structure Research Group, Department of Biophysics, University of \\ London King's College, 26-29 Drury Lane, London WC2B 5RL, England
}

(Received 3 March 1981; accepted 22 May 1981)

\begin{abstract}
6,9-Dichloro-2-methoxyacridine (DCMA), $\mathrm{C}_{14} \mathrm{H}_{9} \mathrm{Cl}_{2}-$ NO, is triclinic, $P$ i, with $a=7.735(1), b=8.651$ (1), $c=10.344$ (1) $\AA, \alpha=95.63$ (1), $\beta=101.80$ (1), $\gamma=113.25(1)^{\circ}, U=603 \cdot 7 \AA^{3}, Z=2 ; D_{m}=$ $1.52(2), D_{c}=1.530 \mathrm{Mg} \mathrm{m}^{-3}, F(000)=284, \lambda(\mathrm{Cu}$ $K \alpha)=1.5418 \AA, \mu=4.701 \mathrm{~mm}^{-1} .2428$ reflections were measured, of which 1999 had significant intensities. Refinement by full-matrix least-squares methods gave a final $R$ factor of $0 \cdot 040$. The structure consists of centrosymmetrically related, stacked molecules. The acridine mucleus is slightly buckled, and does not show mirror symmetry along the $\mathrm{C}(9)-\mathrm{N}(10)$ line. The addition of the $\mathrm{Cl}$ atom at $\mathrm{C}(9)$ has produced significant shortening in adjacent bonds, compared to acridines with a $\mathrm{Cl}$ atom at $\mathrm{C}(6)$ alone.
\end{abstract}

\section{Introduction}

The biological activity of acridine derivatives is often manifest in their mutagenic properties. These have been attributed (Albert, 1966; Waring, 1972; Neidle, 1979), at least in part, to interactions with nucleic acids, particularly DNA. The hypothesis (Lerman, 1961) that

0567-7408/82/010159-04\$01.00 the planar chromophore common to the acridines is involved in stacking interactions with the planar pyrimidine-purine base-pairs, has received support from a large body of physical and biological data, including X-ray crystallographic studies on dinucleoside complex-model systems [for example Berman et al. (1979)].

The present study reports crystallographic data on an acridine derivative with two chlorine substituents; several analyses have been documented on 6-chlorosubstituted acridines (for references see the discussion section), and one on 9-chloroacridine (Achari \& Neidle, 1977). This analysis reveals the electronic effect of dichloro substitution on the acridine-ring-system geometry and the stacking properties of the planar chromophore. The relationship of these to mutagenic activity is currently being explored in these laboratories.

\section{Experimental}

Pale-yellow elongated prisms of DCMA were grown from ethanolic solution. Preliminary oscillation and Weissenberg photographs indicated triclinic symmetry. Accurate cell dimensions were obtained from measure(c) 1982 International Union of Crystallography 
ment of $25 \theta$ values on an Enraf-Nonius CAD-4 diffractometer. Space group $P \overline{1}$ was confirmed by the structure analysis.

A crystal of approximate size $0.3 \times 0.1 \times 0.1 \mathrm{~mm}$ was employed for data collection. Intensity data were collected on a CAD-4 diffractometer using an $\omega-2 \theta$ scan technique. A total of 2428 reflections were measured with $\mathrm{Cu} K a$ radiation $\left(1.5<\theta<70.0^{\circ}\right)$ and of these, 1999 were considered to have significant intensity $[I>2 \cdot 5 \sigma(I)]$. A periodic check on three standard reflections showed that there was no crystal decomposition during data collection.

The structure was solved by direct methods with MULTAN (Germain, Main \& Woolfson, 1971), implemented on the Enraf-Nonius $S D P$ program system. Full-matrix least-squares refinement of all non-hydrogen-atom positional and anisotropic thermal parameters, together with $\mathrm{H}$-atom positional and isotropic thermal parameters, converged to a final $R$ of 0.040 , and $R_{w}$ of 0.056 for the 1999 observed reflections. The positions of all the $\mathrm{H}$ atoms had previously been observed in a difference Fourier

Table 1. Non-hydrogen-atom positional parameters $\left(\times 10^{4}\right)$, and equivalent isotropic thermal parameters

\begin{tabular}{lrccc} 
& \multicolumn{1}{c}{$y$} & $z$ & $B_{\mathrm{eq}}\left(\AA^{2}\right)$ \\
$\mathrm{Cl}(1)$ & $5484(1)$ & $8600(1)$ & $1108(1)$ & $4 \cdot 93(1)$ \\
$\mathrm{Cl}(2)$ & $5489(1)$ & $1540(1)$ & $3930(1)$ & $4 \cdot 31(1)$ \\
$\mathrm{O}(2)$ & $10386(2)$ & $3274(2)$ & $8786(2)$ & $5 \cdot 18(3)$ \\
$\mathrm{N}(10)$ & $8592(2)$ & $7363(2)$ & $5454(2)$ & $3 \cdot 45(3)$ \\
$\mathrm{C}(1)$ & $8461(3)$ & $3366(3)$ & $6652(2)$ & $3 \cdot 82(4)$ \\
$\mathrm{C}(2)$ & $9783(3)$ & $4119(3)$ & $7874(3)$ & $4 \cdot 15(4)$ \\
$\mathrm{C}(3)$ & $10698(3)$ & $5961(3)$ & $8298(3)$ & $4 \cdot 15(5)$ \\
$\mathrm{C}(4)$ & $10273(3)$ & $6977(3)$ & $7506(2)$ & $3 \cdot 83(5)$ \\
$\mathrm{C}(5)$ & $7029(3)$ & $7842(3)$ & $3414(2)$ & $3 \cdot 66(4)$ \\
$\mathrm{C}(6)$ & $5770(3)$ & $7198(3)$ & $2161(2)$ & $3 \cdot 85(4)$ \\
$\mathrm{C}(7)$ & $4665(3)$ & $5389(3)$ & $1651(2)$ & $3 \cdot 75(4)$ \\
$\mathrm{C}(8)$ & $4932(3)$ & $4269(3)$ & $2401(2)$ & $3 \cdot 54(4)$ \\
$\mathrm{C}(9)$ & $6662(3)$ & $3760(2)$ & $4519(2)$ & $3 \cdot 26(4)$ \\
$\mathrm{C}(11)$ & $8916(3)$ & $6255(2)$ & $6203(2)$ & $3 \cdot 33(4)$ \\
$\mathrm{C}(12)$ & $7991(3)$ & $4411(2)$ & $5790(2)$ & $3 \cdot 39(4)$ \\
$\mathrm{C}(13)$ & $6263(3)$ & $4843(2)$ & $3710(2)$ & $3 \cdot 24(4)$ \\
$\mathrm{C}(14)$ & $7314(3)$ & $6679(2)$ & $4225(2)$ & $3 \cdot 27(4)$ \\
$\mathrm{C}(2 \mathrm{Me})$ & $9445(4)$ & $1418(3)$ & $8490(3)$ & $5 \cdot 87(6)$
\end{tabular}

Table 2. Hydrogen-atom positional parameters $\left(\times 10^{3}\right)$ and isotropic thermal parameters

\begin{tabular}{lrrrr} 
& \multicolumn{1}{c}{$x$} & \multicolumn{1}{c}{$y$} & \multicolumn{1}{c}{$z$} & $B\left(\AA^{2}\right)$ \\
$\mathrm{H}(1)$ & $784(3)$ & $217(3)$ & $638(2)$ & $4.9(6)$ \\
$\mathrm{H}(3)$ & $1156(3)$ & $636(3)$ & $915(3)$ & $6.2(7)$ \\
$\mathrm{H}(4)$ & $1093(3)$ & $829(3)$ & $780(2)$ & $4.5(5)$ \\
$\mathrm{H}(5)$ & $771(3)$ & $906(3)$ & $377(2)$ & $4.4(5)$ \\
$\mathrm{H}(7)$ & $382(3)$ & $509(2)$ & $78(2)$ & $3.7(5)$ \\
$\mathrm{H}(8)$ & $421(3)$ & $307(3)$ & $204(2)$ & $5.0(6)$ \\
$\mathrm{H} 1(\mathrm{Me})$ & $959(3)$ & $100(3)$ & $764(3)$ & $6.4(7)$ \\
$\mathrm{H} 2(\mathrm{Me})$ & $801(4)$ & $98(3)$ & $846(3)$ & $7.9(8)$ \\
$\mathrm{H} 3(\mathrm{Me})$ & $1012(4)$ & $113(3)$ & $926(3)$ & $8.0(8)$
\end{tabular}

The average $\mathrm{C}-\mathrm{H}$ bond distance is 0.96 (2) $\AA$. synthesis. Weights used were of the form $w=1 /$ $\left|\sigma^{2}\left(F_{0}\right)+0.03 F_{o}^{2}\right|$. Coordinates and thermal parameters are given in Tables 1 and 2.* All calculations were carried out using the $S D P$ package, implemented on a PDP 11/34A computer.

\section{Results and discussion}

The molecular structure of DCMA is shown in Fig. 1, together with the numbering scheme employed. Tables 3 and 4 detail the bonding geometry of the molecule.

* Lists of structure factors and anisotropic thermal parameters have been deposited with the British Library Lending Division as Supplementary Publication No. SUP 36252 (19 pp.). Copies may be obtained through The Executive Secretary. International Union of Crystallography, 5 Abbey Square. Chester CHI 2HU. England.

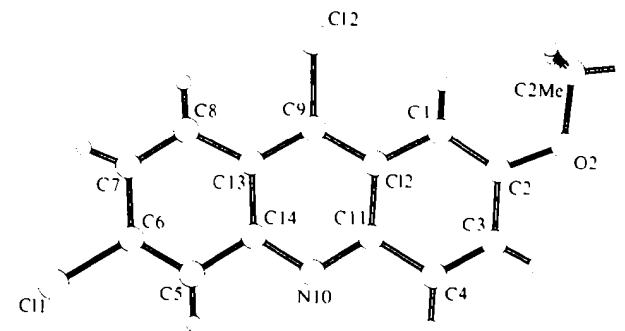

Fig. 1. The molecular structure of DCMA showing the atomic numbering.

Table 3. Bond distances $(\AA)$ in DCMA, together with distances in other acridine structures

$\begin{array}{ccccc}\text { DCMA } & (a) & (b) & (c) & (d) \\ 1.744(1) & 1.726 & 1.743 & 1.738 & \\ 1.730(1) & & & & 1.744 \\ 1.360(2) & 1.359 & 1.370 & 1.363 & 1.381 \\ 1.418(2) & 1.420 & 1.418 & 1.420 & 1.421 \\ 1.427(2) & 1.410 & 1.395 & 1.409 & 1.409 \\ 1.360(2) & 1.380 & 1.371 & 1.366 & \\ 1.338(2) & 1.350 & 1.340 & 1.361 & 1.355 \\ 1.430(2) & 1.414 & 1.422 & 1.433 & 1.437 \\ 1.361(2) & 1.364 & 1.345 & 1.360 & 1.358 \\ 1.416(2) & 1.413 & 1.425 & 1.428 & 1.433 \\ 1.420(2) & 1.402 & 1.395 & 1.406 & 1.416 \\ 1.343(2) & 1.357 & 1.359 & 1.357 & 1.361 \\ 1.426(2) & 1.430 & 1.418 & 1.437 & 1.429 \\ 1.395(2) & 1.449 & 1.441 & 1.425 & 1.407 \\ 1.389(2) & 1.431 & 1.421 & 1.419 & 1.397 \\ 1.340(2) & 1.362 & 1.356 & 1.352 & 1.338 \\ 1.349(2) & 1.356 & 1.350 & 1.341 & 1.362 \\ 1.435(2) & 1.408 & 1.414 & 1.421 & 1.449 \\ 1.437(2) & 1.425 & 1.428 & 1.437 & 1.434 \\ 1.431(2) & 1.417 & 1.416 & 1.422 & \end{array}$

(a) Quinacrine; 6-chloro-9-\{|4-(diethylamino)-1-methylbutyl\}amino $\}$-2-methoxyacridine (Courseille. Busetta \& Hospital, 1973). E.s.d.'s range from $0 \cdot 003-0.004 \AA$.

(b) ICR-191-OH; 2-|3-(6-chloro-2-methoxy-9-acridinylamino)propylaminolethanol (Carrell, 1972). E.s.d.'s average 0.003 $\AA$.

(c) ICR-170-OH; 2-13-(6-chloro-2-methoxy-9-acridinylamino)propyl(ethyl)aminolethanol (Berman \& Glusker, 1972). E.s.d.'s average $0.006 \AA$.

(d) 9-Chloroacridine (Achari \& Neidle, 1977). E.s.d.'s average $0.006 \AA$. 
The acridine nucleus of DCMA does not show exact mirror symmetry along the $\mathrm{C}(9)-\mathrm{N}(10)$ line, as has been found for simple acridines such as 3,6-diaminoacridine (Jones \& Neidle, 1975). This is not unexpected in view of the electronic effect of the non-symmetrical ring substitution pattern. Thus, bonds $\mathrm{C}(5)-\mathrm{C}(6)$ and $C(3)-C(4)$ differ in length by over $10 \sigma$; other pairs

Table 4. Bond angles $\left({ }^{\circ}\right)$ in $D C M A$

$\begin{array}{ll}C(2)-C(1)-C(12) & 120 \cdot 0(1) \\ C(1)-C(2)-C(3) & 120 \cdot 5(1) \\ C(1)-C(2)-O(2) & 125 \cdot 9(1) \\ C(3)-C(2)-O(2) & 113 \cdot 6(1) \\ C(2)-C(3)-C(4) & 120 \cdot 8(1) \\ C(3)-C(4)-C(11) & 121 \cdot 5(1) \\ C(6)-C(5)-C(14) & 119 \cdot 3(1) \\ C(5)-C(6)-C(7) & 122 \cdot 3(1) \\ C(5)-C(6)-C l(1) & 120 \cdot 2(1) \\ C(7)-C(6)-C l(1) & 117.4(1) \\ C(6)-C(7)-C(8) & 119 \cdot 1(1) \\ C(7)-C(8)-C(13) & 121 \cdot 8(1) \\ C(12)-C(9)-C(13) & 121.9(1) \\ C(12)-C(9)-C l(2) & 119 \cdot 0(1) \\ C(13)-C(9)-C l(2) & 119 \cdot 1(1)\end{array}$

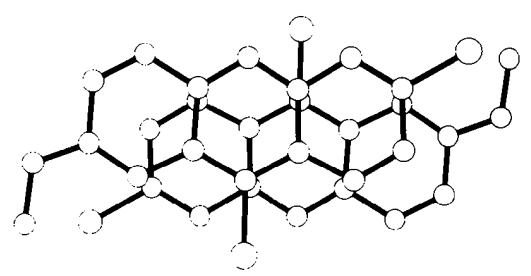

Fig. 2. The stacking of two centrosymmetrically related molecules.

Table 5. Deviations (in $\AA$ ) of atoms from various least-squares planes

Atoms marked with an asterisk were excluded from the planes' calculation. E.s.d.'s are 0.002-0.003 Å.

$\begin{array}{lccc} & \text { Plane 1 } & \text { Plane 2 } & \text { Plane 3 } \\ \mathrm{C}(1) & 0.001 & & 0.031 \\ \mathrm{C}(2) & -0.001 & & 0.033 \\ \mathrm{C}(3) & 0.005 & & 0.012 \\ \mathrm{C}(4) & -0.008 & & -0.029 \\ \mathrm{C}(5) & & -0.006 & 0.027 \\ \mathrm{C}(6) & & 0.017 & 0.060 \\ \mathrm{C}(7) & & -0.012 & 0.000 \\ \mathrm{C}(8) & & -0.003 & -0.030 \\ \mathrm{C}(9) & -0.002^{*} & 0.073^{*} & -0.030 \\ \mathrm{C}(11) & 0.007 & 0.038^{*} & -0.008 \\ \mathrm{C}(12) & -0.004 & 0.087^{*} & -0.004 \\ \mathrm{C}(13) & 0.010^{*} & 0.014 & -0.027 \\ \mathrm{C}(14) & 0.043^{*} & -0.009 & -0.019 \\ \mathrm{C}(2 \mathrm{Me}) & -0.065^{*} & & 0.025^{*} \\ \mathrm{O}(2) & 0.026^{*} & & 0.088^{*} \\ \mathrm{~N}(10) & 0.030^{*} & -0.008^{*} & -0.026 \\ \mathrm{Cl}(1) & & 0.099^{*} & 0.193 \\ \mathrm{Cl}(2) & 0.002^{*} & & 0.026\end{array}$

Angle between planes 1 and $2: 3 \cdot 1(2)^{\circ}$. such as $\mathrm{C}(6)-\mathrm{C}(7), \mathrm{C}(2)-\mathrm{C}(3)$, and $\mathrm{C}(7)-\mathrm{C}(8)$, $\mathrm{C}(1)-\mathrm{C}(2)$ are also non-equivalent, the latter rather more so. Table 3 highlights some comparisons of DCMA bond lengths with those in other $\mathrm{Cl}$-substituted acridines. The introduction of the strongly electronegative $\mathrm{Cl}$ atom at $\mathrm{C}(9)$ has, compared to quinacrine (Courseille, Busetta \& Hospital, 1973), ICR-191-OH (Carrell, 1972) and ICR-170-OH (Berman \& Glusker, 1972), markedly shortened the $C(9)-C(12)$ and $\mathrm{C}(9)-\mathrm{C}(13)$ bond lengths. This shortening in DCMA, of an average of $0.04 \AA$, is also shown in 9-chloroacridine (Achari \& Neidle, 1977). The resulting increase in electron deficiency of the acridine nucleus in DCMA compared to the non-C(9)-chlorinated compounds could result in an enhanced propensity for stacking interactions with other planar moieties, for example, in a nucleic acid.

Examination of Table 4 shows that the majority of valence angles have their expected trigonal-hybridization values. There is significant distortion around $\mathrm{C}(2)$, with angle $\mathrm{C}(3)-\mathrm{C}(2)-\mathrm{O}(2)$ having a low value and $\mathrm{C}(1)-\mathrm{C}(2)-\mathrm{O}(2)$ a high one. Similar angle asymmetry has been noted in other 2-methoxyacridines; in the present case it may be explicable in terms of the stacking association of adjacent molecules (Fig. 2). $\mathrm{Cl}(1)$ of one molecule lies close to the 2-methoxy group of another; the two groups would tend to repel each other, resulting in angle asymmetry around $\mathrm{C}(2)$ and $\mathrm{C}(6)$.

Table 5 shows that both the outer benzene rings of the acridine are closely planar, but are not coplanar with each other. The ring system overall thus has a slight degree of buckling, a phenomenon commonly observed in acridine structures (Jones \& Neidle, 1975).

The DCMA molecule in the crystal forms a centrosymmetric stacking association (Figs. 2, 3), with a ca $3.4 \AA$ plane separation. The overlap between two adjacent molecules (Fig. 2) involves all three six-

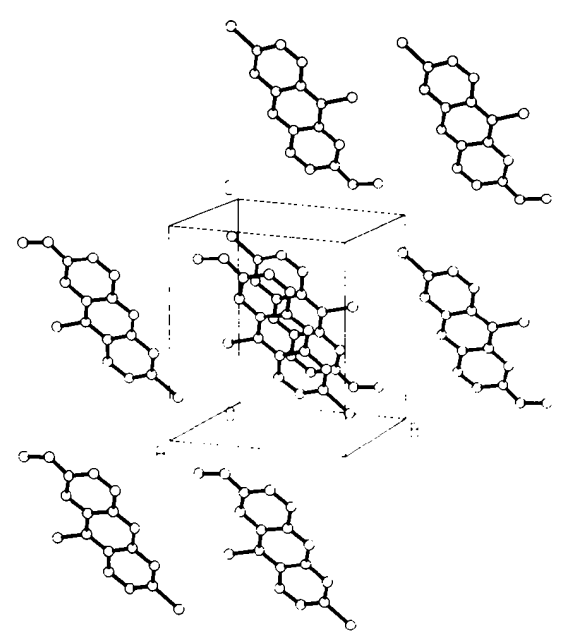

Fig. 3. View of the crystal structure. 
membered rings of the acridine nucleus. More extensive overlap would involve sterically unacceptable interactions between $\mathrm{Cl}(1)$ and the 2-methoxy group.

This research was supported by the Cancer Research Campaign (Grant SP1384), who are also thanked for a Career Development Award.

\section{References}

Achari, A. \& Neidle. S. (1977). Acta Crist. B33. 3269-3270.

Albert, A. (1966). The Acridines, 2nd ed. London: Edward Arnold.
Berman, H. M. \& Glusker, J. P. (1972). Acta Cri'st. B28. 590-596.

Berman, H. M.. Stallings, W.. Carrell, H. L.. Glusker, J. P.. Neidle, S.. Achari. A. \& TAYlor. G. (1979). Biopolymers, 18, 2405-2429.

Carrell. H. L. (1972). Acta Cryst. B 28. 1754-1759.

Courseille, C.. Busetta. B. \& Hospital. M. (1973). Acta Crist. B29. 2349-2355.

Germain, G.. Main, P. \& Woolfson, M. M. (1971). Acta Crist. A 27, 368-376.

Jones. A. \& NeIDle. S. (1975). Acta Crist. B31. 13241333.

LERMAN, L. S. (1961). J. Mol. Biol. 3. 18-30.

Neidle, S. (1979). Prog. Med. Chem. 16. 151-221.

WARING. M. J. (1972). The Molecular Basis of Antibiotic Action. London: John Wiley.

Acta Cryst. (1982). B38, 162-168

\title{
Complexe Naphtalène-Dianhydride d'Acide Pyromellitique (N-PMDA). II. Calculs d'Energie Potentielle Intermoléculaire et Réorientations Moléculaires dans les Deux Formes Jaune et Orange
}

\author{
PAR M. Le Bars-Combe et J. LAJZÉrowicz-Bonneteau
}

Université Scientifique et Médicale de Grenoble, Laboratoire de Spectrométrie Physique, Boîte postale $n^{\circ} 53$, 38041 Grenoble CEDEX, France

(Reçu le 20 janvier 1981, accepté le 22 mai 1981)

\begin{abstract}
Available crystal structure data have been used to calculate the dependence of van der Waals potential energy on molecular reorientation of two forms of naphthalene-pyromellitic dianhydride (N-PMDA), a weak charge-transfer crystal. In the yellow form, the results of the calculations agree with the results of $\mathrm{X}$-ray analysis and NMR, i.e. an ordered structure with possible occurrence of large in-place reorientations of $180^{\circ}$ for naphthalene molecules. In the orange form, the calculations made at $293 \mathrm{~K}$ and $153 \mathrm{~K}$ are consistent with a disordered room-temperature structure and an order-disorder transition. In-plane reorientations of naphthalene molecules of about $40^{\circ}$ occur at room temperature, but no large reorientations seem possible. The possible existence has been found of another orientation for naphthalene molecules, which may be occupied by a small percentage of the molecules. A satisfactory correlation was found between the root-mean-squared amplitudes of libration and the results of potential-energy calculations.
\end{abstract}

0567-7408/82/010162-07\$01.00

\section{Introduction}

Les structures à température ambiante des deux formes jaune et orange du complexe $1 / 1$ naphtalène-dianhydride d'acide pyromellitique, un des complexes de type $\pi-\pi^{*}$ à faible transfert de charge, ont été publiées (Le Bars-Combe, Chion \& Lajzerowicz-Bonneteau, 1979). Le changement de phase ordre-désordre que présente la forme orange à $188 \mathrm{~K}$ ainsi que la structure de la forme basse température (LT) ont également été étudiées (Le Bars-Combe \& Lajzérowicz-Bonneteau, 1981).

Dans cet article, nous utilisons ces renseignements structuraux pour évaluer dans les différents cas, l'énergie potentielle intermoléculaire. Ceci a plusieurs objectifs: voir si l'on retrouve au niveau des calculs d'énergie les situations d'ordre ou de désordre observées pour les molécules de naphtalène, confirmer les hypothèses sur les réorientations moléculaires qui avaient été avancées à partir des mesures de RMN, comparer les résultats sur l'agitation thermique des molécules déduits des courbes d'énergie avec ceux issus des données de la diffraction $\mathrm{X}$.

(C) 1982 International Union of Crystallography 